\title{
Immigrants' housing in the housing market in Russia: from the results of sociological questionnaire
}

\author{
M. Michigami \\ Niigata University (National University) \\ 8050, Ikarashi 2-no-cho, Nishi-ku, 950-2181, Niigata, Japan
}

\begin{abstract}
The study is based on the results of an original sociological survey conducted in 25 cities of Russia from June 2017 to March 2018 by the author. This paper focuses especially on labour immigrants from Central Asia, Ukraine, Belarus and Caucasus regions into Russia. This paper argues the following points; first, the correlation between the demographic movements and regional rental housing fee in Russia, second, the multi-layered structure and its informality of Russian housing market, finally, the relation between labour migrants' housing condition and labour productivity.

In the conclusion, the author points that the Russian housing market is segregated from this research results. Migrant's housing deals are possibly the origin or bottom of the housing market. Their activity would move the regional housing rental market. However, some of their deals also seem to be invisible in the official housing statistics, that is to say, taking place in the informal housing market. This regards as one of characters, which Russian rental housing market has. It would be hurdle for foreign direct investor, which would invest into Russian market. In addition, the quality of immigrants' housing condition is too low to support their labour productivity sustainably. We need to consider the improvement even for labour immigrants and the creation of more open housing market in Russia.
\end{abstract}

Keywords: housing, immigrant, segregation, informality, multi-layered structure, rental housing market, Russia

\section{Introduction}

One of our unique research aspect is the relation between immigrants' housing and Russian regional housing market. Russia is one of countries in the world, which accept many labor migrants. Labor migrant's demographic movement would create to a considerable degree the volume of housing demand - especially rental housing demand in Russia. We try to approach the fundamental drives of Russian housing market from the bottom or origin of market. For this purpose, we originally did questionnaire survey about immigrant's housing, job, life and problems in Russia and collected 1003 respondents in the total 25 cities all around of Russia. Our amount of respondents are large scale of previous researches. We will investigate our following hypothesis by our original sociological questionnaire survey.

First, immigrant inflow does not reflect on the level of housing price in the districts, of their living intensely in Russia. Second, immigrant inflow reflect on the structure of housing market in Russia, we termed, the multi-layered structure. Third, their usual way of housing transaction leads the invisibleness of housing market in Russia. Finally, the 
problems of immigrant's housing condition and housing finding reflect on the sustainability of immigrant labor productivity and Russian sustainable growth. In this paper, we introduce some of our first results by questionnaire survey and give our answer against the hypothesis.

In the previous literature, they mainly have discussed the governance aspects against immigrant inflow in the urban districts, especially in the city of Moscow. For example, the segregation of immigrant districts and the correlation between urban enlargement and immigrant. As far as we can see, there is very little literature that focused on our second, third, and fourth hypothesis. Therefore, our research has an academic uniqueness and significance to approach immigrants' reality in Russia. In the next section, we follow the previous literature view.

\section{Literature review}

Now we can discuss a hypothesis: Do immigrants' inflow reflect housing price or rental fee - giving a pressure downward or upward? The previous literatures are divided into two views. On the one hand, ethnic and cultural conflict among immigrants settlement bring downward housing price in the high density district of immigrants (Ashkenazi, Vekshtein, 2009; Demintseva, 2014, 2017; Vendina, 2004, 2005; Zaionchkovskaya et al., 2009). Increasing of immigrant from Central Asia and Caucasian reflected the housing price level of their residential districts in Moscow. They had researched the case of Moscow city. In some geographer and demographer's previous literature (Vendina, 2004, 2005; Zaionchikovskaya et al., 2009; Fedotenkov, Mikolajun, 2013; Limonov, Nesena, 2016), they researched the urban space pattern of immigrant labor settlement and their life culture, where do they live in Moscow. Especially since 90's increasing immigrant inflow into Moscow have brought some phenomenon of urban Moscow: 1) the downward pressure of housing price in some districts of Moscow, 2) the urban agglomeration and enlargement, 3) high density of population, 4) ethnic and cultural conflict between residents and immigrants. To sum them up simply, they consider the urban space management connected with migration administration. In fact, it is difficult to segregate immigrant residents in Moscow and Russian regions. Therefore, their implicit message is not to integrate but to control immigrants, beside it, to do segregate them if possible in Russia.

On the other hand, Kashnitsky and Gunko (2016) pointed econometrically that we could not find the correlation between housing prices and intensities of in-migration at the level of city districts of Moscow. First, it is difficult for us to prove it econometrically that increasing of immigrant inflow into some of city districts would reflect on the housing price or rental fee level of their residential districts in Moscow. The level of price and rental fee are affected complicatedly by multiple reasons: population movement, business cycle, interest rate, the volume of new housing construction, and the city's urban development plan, etc.

In addition to it, Ashkenazi and Vekshtein (2009) shows the fact that the lender prefers to lend their apartment for only Russian to prevent from some ethnic conflictions from Central Asia and Caucasus and trouble caused by such confliction. This phenomenon shows another aspect of reflects about the correlation between housing market and immigrant inflow. It might bring the segregation of housing market, especially rental 
housing market in Russia. Immigrants' inflow does not give a direct reflection to the housing rental-selling price. Immigrant inflow creates another segment of housing market in Russia. There is "divided market" of housing between foreign businessperson, Russian and immigrant labor.

Figure 1 is Rosstat data's housing price map by Russian Federation. These three solid lined circle are regions that typically accept immigrant labor. Three areas' housing price level is higher than federal average (Federal average 46.4 thous. per sq.m). These areas shows that immigrants' inflow might give a pressure upward housing price. As far as we go to the case of Moscow and some regions, it seems that immigrant inflow would reflect the regional housing price of Russia.

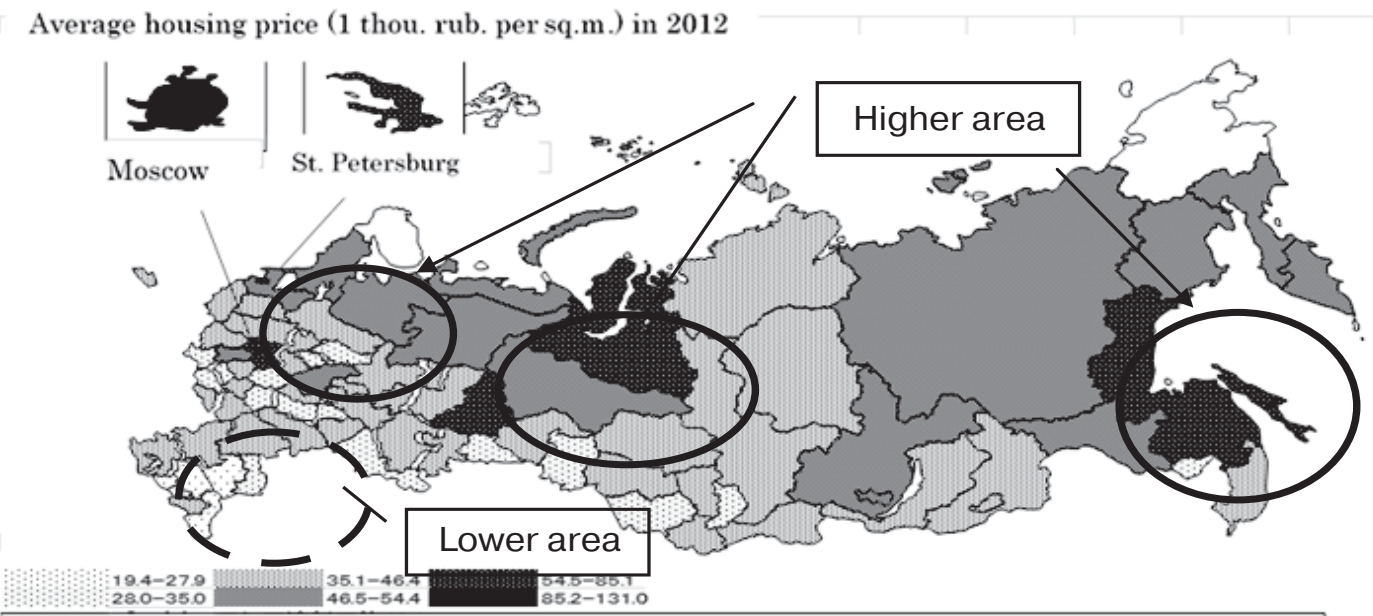

White: n.a. Average of Russian Federation: 46.6

Figure 1. Average housing price (1 thou. rub. per sq.m.) in 2012

Source: Rosstat (2012) and Michigami (2016).

However, on the level of Russian Federation, we cannot make a clear, immigrant labor reflect housing price or not. The one dotted lined circle is region, which is lower price than average, though this area is also the region that typically accept immigrant labor. Therefore, we would like to confirm it by our survey.

We have the original image of housing market in Russia. That is "multi-layered structure" of housing market in Russia (figure 2, Michigami, 2017). Russia's housing market has some stratum according to categorized customers' demand: elite class, business class, economy class, and rental apartment, studio, dormitory, dacha, container, etc. The bottom is for labor migrants' housing circulation at the purpose of using temporal residence according to their level of rental fee. We regard their transaction of housing as the nature of origin of market. Their deals mainly connect through word of mouth, between individuals, relatives and acquaintance. By climbing up the stratum, there deals circulate through real-estator. In addition, their housing use is regular settlement and their transaction is mainly selling and buying. It seems that the mobility and volume of housing 
deals at the bottom are higher and larger than the one of upper side. The temporal rental housing market mainly circulates on the bottom of housing market. Most of them are the demand of immigrant labor into Russia. They might reflect to all of Russia's housing market dynamics through the price discrimination. We will try to confirm this our original image and idea with our questionnaire survey.

Here, we add another academic topic 'price discrimination' on micro economic theory in this discussion. From the real estator's website of Moscow (for example, TSIAN), we can see that housing lenders provide two types price for foreigners or use the constraint condition depending on the customers (figure 3). In actual, the author had the same experience during finding apartment at Moscow and Saint Petersburg in 2017.

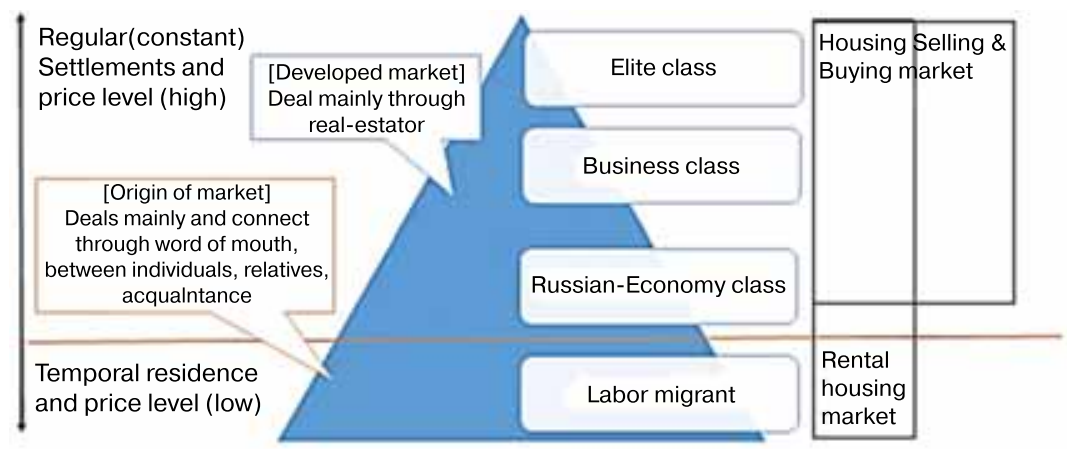

Figure 2. Images of multi-layered structure of Russia's housing market

Source: Author's compiled (Michigami, 2017).

Moscow city's rental housing website by real-estator TSIAN 's case

2-коми. кв. на длительныи срок (от года)

45000 pyo. o mecsu

Two rooms apartment for more than 1 year; 45 thou. Rub. monthly

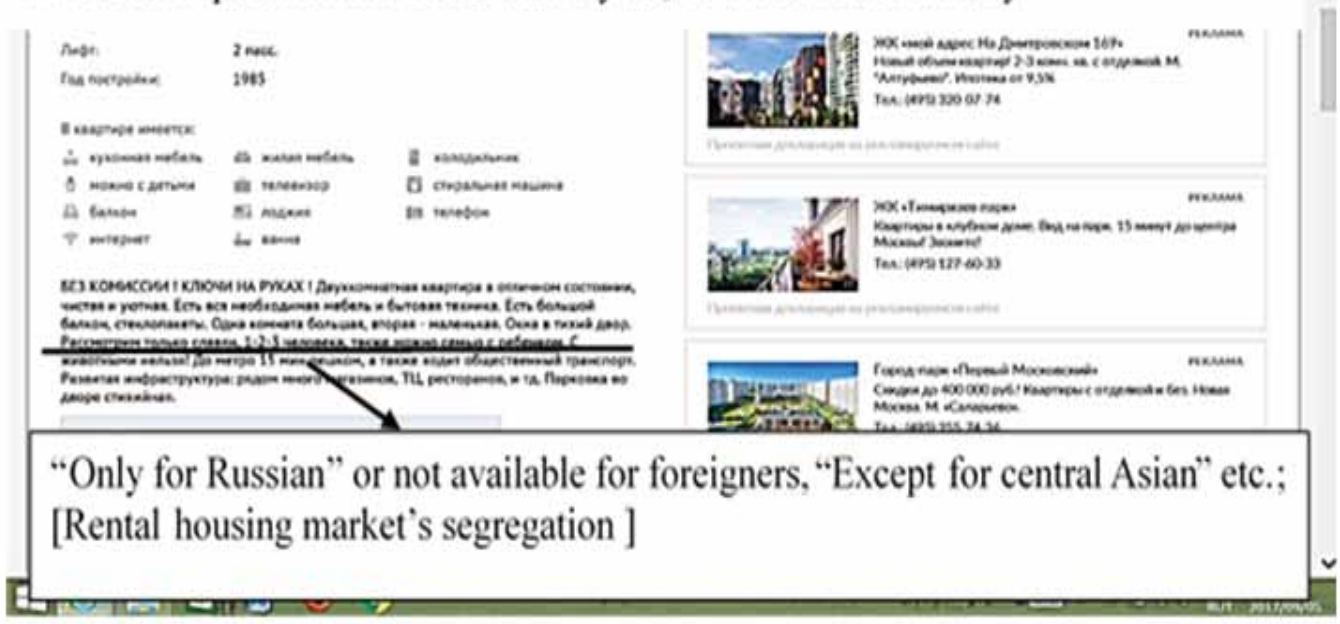

Figure 3. How can foreigner and migrant labor find their temporal housing?

Source: Author's compiled with TSIAN website (2017). 
In figure 3, one renter presented 45 thousand ruble as monthly rent for two rooms apartment at the South-West area of Moscow. In Russia, such kind of TSIAN website is popular for rental housing. In addition, other tourist agency website shows for rental housing. They are useful for foreigner and migrant labor to find their apartment in Russia. This website shows two rooms apartment for renting more than 1 year. In 2017 average monthly rent fee in Moscow by real-estator is the followings (Sternyk consulting, 2017); economy class (standard) built in the era of USSR one room apartment - 30 thousand rub. Two rooms apartment about 37.5 thousand rub. Three rooms apartment 47 thousand rub. (Rossiskaya Gazeta, 2017). Therefore, the website's price level is higher than the average of Moscow. The rent level of this apartment in figure 3 is not affordable for immigrants from Central Asia.

In addition, this renter set such constraint condition that this apartment lends only for Russian and except for Central Asian. It seems it is affordable only for high salary customers. In fact, we can often see such constraint: 'only for Russian' or 'except for Central Asian, etc. Ashkenazi and Vekshtein (2009) discuss this fact directly. It seems that there are the segregation of rental housing market in Russia and some problems related in immigrant labor under urbanization. In addition, this transaction can become the hurdle for foreigner and immigrant labor to find the rental housing.

Beside the condition, from author's investigation, their price level was not stable rigidly. It could negotiate depending on the nationality. Sometimes, the renter use the different price depending on the customers. When foreigner (not Russian language speaker) asked to the renter by phone, the price was as the same as the website. Even with negotiation subjected to rent for longer days, price for foreigner did not depreciate to the half level of website price, but only about $20 \%$ price down. However, when Russian asked to the renter by phone, the price level was firstly the discounted half of price on the website without negotiation. The half level of website price is the almost average level in the analyst's data (Sternyk, etc). From author's investigation, these prices were about double price, not only located in the most center of Moscow but also in other area of Moscow. The price for foreigner is higher, sometimes twice higher than the price level for Russian.

This pricing make us remind 'price discrimination' and 'personalized pricing' in the micro economic theory. Now this topic is discussed about the relevance of e-commerce and the shopping though the internet (Tang, Smith, 2007; Sigarev, Kosov, 2016). In real life, we can see the similar pricing that same goods are sold with different price in the different shop: for example, on the one hand, a same yogurt drink is sold with 38 ruble in store A. On the other hand, it is sold with 51 ruble in store B (expensive store). We also confronted this pricing on the apartment transaction in Moscow. Provider sets the following price for the same rental housing. A) For foreign businessperson - immigrant labor - expensive price (higher than average). B) For Russian - average price. C) For Central Asian and other immigrant labor - don't lend or lower price than average. Sometimes their price is not visible. In micro economic theory, we consider the reason why price elasticity of demand for housing is different between foreign businessperson immigrant (low) and non-skilled immigrant (high). We will try to confirm this our original image and idea 'as multi-layered stratum' of housing market in Russia from the viewpoint of immigrants' housing with our questionnaire survey. 


\section{Methods}

We did the original sociological questionnaire survey 25 cities all over the Russia: Moscow, Podolsk, Chekhov, Serpukhov, Kaluga, Saint Petersburg, Pushkin, Tikhvin, Ekaterinburg, Sysert, Vladivostok, Khabarovsk, Ussuriysk, Partizansk, Dalnerechensk, Surgut, Nefteyugansk, Langepas, Lyantor, Tomsk, Stavropol, Blagodarny, Pyatigorsk, Budyonnovsk, and Neftekumsk. We asked 68 questions against immigrant not only housing conditions but also daily life and their job. For example, the reason to come to Russia, the kind of job, document, problems, housing condition, and rent fee, etc. The term of our questionnaire survey is from June in 2017 to March in 2018. Finally we collected the total number of respondents is 1003 persons (Average age 34.6 y.o. and oldest 65 y.o youngest 18 y.o.). Such questionnaire survey is just a few and valuable that conducted for lots of respondents and in cities all round Russia. Our survey has the uniqueness to ask the real inside of immigrants to make definitely careful consideration to their human rights and privacy.

All of them are legal immigrants with the patent and permission for labor in Russia. The emigrated countries' formation of respondents is the following: Tadzhikistan (344 respondents), Uzbekistan (225), Ukraine (115), Kyrgyzstan (83), Armenia (51), Azerbaijan (42), Belarus (18), Kazakhstan 19, and others (106); China, North Korea, Vietnam, Moldova, Mongolia, Turkey, Italy, Georgia. The sex formation of all respondents is men $79.2 \%$ (average age 34.4 y.o.) and women $20.8 \%$ (average age 20.8 y.o.). The age formation of respondents is to 29 y.o. $-(36.8 \%), 30-39$ y.o. $-(32.2 \%)$, to $40-49$ y.o. $-(23.9 \%)$, older than 50 y.o. $-(6.7 \%)$, n.a. $-(0.4 \%)$.

\section{Results}

Our original questionnairesurvey uniquely shows a lot of real immigrant's housing. In this paper, we focus on the rent fee level of immigrant's rental housing and their real living space for the sake of a space constraint. The average level of one room apartment's rental fee on the real estate website TSIAN - Moscow (tentative calculation by author) is average 16416 ruble, median 16000 ruble, min 5000 ruble, max 38000 ruble. The one of our questionnaire survey at Moscow is average 8527 ruble, median 6000 ruble, min 0 ruble, max 35000 ruble. Our outcome is very lower than market price. All our outcome of housing average fee is shown in table. Now average monthly rent fee in Moscow by real-estator is the followings; economy class (standard) built in the era of USSR one room apartment -30 thousand rub. Two rooms apartment about 37.5 thousand rub. Three rooms apartment 47 thousand rub. (Rossiskaya Gazeta, 2017). These price levels are for Russian people, not for foreigner and migrant labor. We really find low level of immigrant rent and see the bottom aspect of housing market by our questionnaire survey.

Compared between our results of rent fee in 25 cities of Russia and average by author's calculation using the data of popular rental housing website in Russia (Avito.ru), the rent level of immigrant housing is much lower than the average level on the website in all 25 cities. Our result proves that immigrants' rental housing fee and transaction are located on the bottom of housing market in Russia. In addition, it is also found that Russia's rental housing market has one different segment for immigrants. 
Average housing rental fee by region

\begin{tabular}{|c|c|c|c|c|c|c|c|}
\hline Distance & City & $\begin{array}{l}\text { Average } \\
\text { rent } \\
\text { (ruble) }\end{array}$ & \begin{tabular}{c|} 
Average \\
rent per \\
sq.m (ruble)
\end{tabular} & Distance & City & $\begin{array}{l}\text { Average } \\
\text { rent } \\
\text { (ruble) }\end{array}$ & $\begin{array}{l}\text { Average } \\
\text { rent per } \\
\text { sq.m (ruble) }\end{array}$ \\
\hline Center & Moscow & 8527.40 & 273.5 & Center & St. Petersburg & 9250.00 & 238.8 \\
\hline $40 \mathrm{~km}$ & Podolsk & 5350.00 & 160.7 & $24 \mathrm{~km}$ & Pushkin & 5857.14 & 210.0 \\
\hline $80 \mathrm{~km}$ & Chekhov & 5877.55 & 206.3 & 220 km & Tikhvin & 9100.00 & 260.6 \\
\hline 100 km & Serpukhov & 10875.00 & 311.5 & Center & Ekaterinburg & 8176.25 & 309.6 \\
\hline $188 \mathrm{~km}$ & Kaluga & 6533.33 & 229.0 & $50 \mathrm{~km}$ & Sysert & 5438.89 & 132.1 \\
\hline Center & Vladivostok & 8086.90 & 297.7 & Center & Surgut & 5720.45 & 252.2 \\
\hline $100 \mathrm{~km}$ & Ussuriysk & 5946.15 & 201.8 & 46 km & Nefteyugansk & 7955.56 & 322.5 \\
\hline 170 km & Partizansk & 5690.00 & 261.2 & $96 \mathrm{~km}$ & Langepas & 5450.00 & 178.3 \\
\hline $400 \mathrm{~km}$ & Dalnerechensk & 5148.00 & 204.6 & $77 \mathrm{~km}$ & Lyantor & 5738.10 & 143.7 \\
\hline Center & Stavropol & 5911.76 & 251.6 & & & & \\
\hline $116 \mathrm{~km}$ & Blagodarny & 6615.38 & 147.5 & & & & \\
\hline 144 km & Pyatigorsk & 6750.00 & 270.0 & & Khabarovsk & 16297.62 & 436.7 \\
\hline $173 \mathrm{~km}$ & Budyonnovsk & 9300.00 & 244.7 & & Tomsk & 8360.48 & 265.0 \\
\hline $240 \mathrm{~km}$ & Neftekumsk & 4300.00 & 184.5 & & Total Average & 7583.05 & 242.3 \\
\hline
\end{tabular}

Source: author's calculation by results of our questionnaire survey.

According to table, we can see another trend. Usually the rent level of center city is highest of their neighbor regions. Our results show not only the usual figure, but also another fact like 'Donuts phenomenon of urban', that is enlargement of urban, with the respect to rental fee level. The rent level of Serpukhov city is higher than Moscow, which is $100 \mathrm{~km}$ far from the center Moscow region. The level of Tikhvin city is also high as well as the case of Sepukhov city. Average rent per sq.m in Tikhvin is even higher than St. Petersburg, which is $220 \mathrm{~km}$ far from the center city of Leningrad region. The same trend is similarly shown in the Stavropol and Surgut region. The rent level of some cities, which locate far from center city, is high, compared with the level of center. We can regard this trend as some "Relay points of immigrant inflow before their going to big cities" (See figure 4). The image of immigrant movement is drawn on figure 4. Immigrants seem that they move by two steps. For example, on the first step, immigrants move to Tikhvin to stabilize their life. Then, on the second step, they move to Saint Petersburg. Their twostep movement possibly bring upward pressure on the rental fee in the city located as 'relay point'.

We have gotten the other following results about housing condition of immigrants. First, about co-living, most of them live in one apartment with three persons including himself. Co-living with 3 persons is $32.8 \%$, with 2 persons $-19.2 \%$, with 4 persons $14.5 \%$, with 5 persons $-7.3 \%$, with 6 persons $-1.5 \%$, with 7 persons $-2.8 \%$, with more than 8 persons $-1.7 \%$, and alone $-13.5 \%$. Second, about living space area of immigrants' apartment/room, average living space was 31.3 sq.m and average living space per capita was 10.8 sq.m. Compared with Rosstat's data in Russian Federation: average living space -54.5 sq.m and average living space per capita -24.4 sq.m, immigrant's living space was quite small. In addition, most of immigrants in our survey (32.6\%) live in a apartment/room to $10-20$ sq.m, $24.9 \%$ - to $20-30$ sq.m, $17.5 \%$ - to $30-40$ sq.m, 
$9.9 \%$ - to $40-50$ sq.m, $7.1 \%$ - to $50-60$ sq.m, $3.7 \%$ - to $60-70$ sq.m, $2.7 \%$ - to less than 10 sq.m, and $1.6 \%$ - more than 71 sq.m. Our results proves that immigrant's housing space falls seriously under Russian government goals (per capita 21.7 sq.m and the standard for 3 persons -54 sq.m). Their housing is the place for immigrants to live, keep working, support their family and "re-product of labor force by K. Marx". Their housing condition should improve to support their quality of life, and labor productivity with the respect to human resource government. Fourth, therefore, we find immigrants' housing problem is narrow and crowded space. Most of immigrants in our survey $(30.7 \%)$ dissatisfy with 'narrow and small space' of their housing. Other dissatisfaction about their housing are $24.6 \%$ with non-repaired, $13.6 \%$ with expensive rent fee, $11.6 \%$ with noisy, $10.6 \%$ with darkness of housing, $10.4 \%$ with coldness, $10.3 \%$ with bad ventilation, and $4.5 \%$ with dirty.

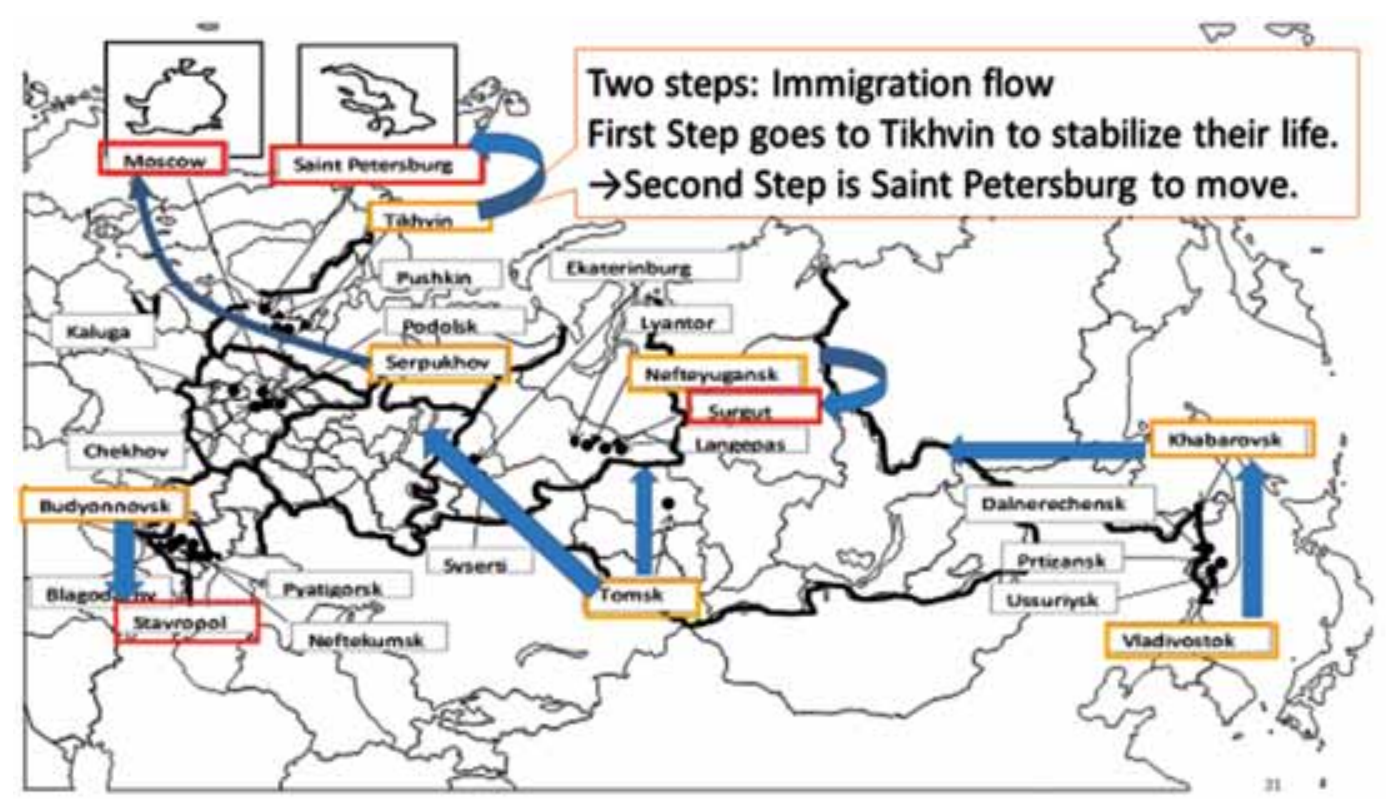

Figure 4. The image of immingrants' two step movement

Source: author's compiled.

Fifth, 66.8\% immigrants in our survey rent apartment/room. Immigrants living at the working place $(13.8 \%)$ are often shown in the construction site of city, etc. Immigrants living at the dormitory and employer's housing were about $20 \%$. We find that it is much lesser that the employer of immigrants itself supply the housing for immigrant compared with the USSR era. It exactly showed that immigrants' labor benefit with the respect to housing has translated by housing market. Our survey proves, however, that they do not use the official housing market channel on finding their rental housing. Sixth, immigrants who find their housing through real estator were only $10.1 \%$ in our survey. Most of them find it by relatives and fellow compatriot (27.2\%), and friends and colleagues at working place $(24.2 \%)$. In addition, through internet (11.1\%) and newspaper (6.2\%) immigrants finds. Immigrants who find their housing through their employer were $21.2 \%$. Roughly, $90 \%$ immigrants find their housing use a channel among mouth of word by individuals, 
and their personal connection, not agency. This fact brings the invisibleness and informality of rental housing market into Russia. Furthermore, their transaction tool reflect the unclearness of correlation between official price statistics and immigrant inflow. In addition to it, it can divide the housing market into official and unofficial. In this paper, official market means that agency and customer make the official contract and agency pay tax for their profit. Immigrants who signed a contract of housing rental were $50.1 \%$ in our survey. Other $49.9 \%$ immigrants lend their housing without the contract. It means unofficial and their rent fee does not reflect the official statistics. Our survey confirm our image of multi-layered structure of housing market and its informality. This informality and invisibleness cause a hurdle for foreign capital to invest into Russian real estate market. Furthermore, our survey shows about registration and mobility of their rental housing, but we will add that in another paper.

\section{Conclusions}

In this paper, we focused on immigrants' real housing environment and the reflection of their transaction on the housing market in Russia. We prove the following facts from our results: 1) in some special area, that located as 'relay point' of immigrant movement, there is possibly a correlation between the immigrant inflow and regional rental housing fee. Our survey newly and concretely pointed the existence of two-step movement in 25 cities of Russia; 2) immigrants' rental housing fee is very low than the average of official data. Half of their transaction are invisible and informal. Therefore, immigrant's housing deals are inherited from the USSR era. It is possibly the origin or bottom of the housing market. In addition, the segment for immigrants exists in the Russian housing market. It shows the multi-layered structure of this market; 3 ) immigrants' housing space is very small than Russian Federation's average and goal. The quality problem are a narrow space and non-repaired room. Most of them live with 3 persons not family. Their housing is not enough for them to rest. If we approach to improve their housing environment, we can increase labour productivity sustainably. Even depending on their rental term, we should consider the improvement of their housing environment. For this purpose, we need to make a policy that organize private rental housing market more openly and clearly through private agency. We can consider some options: the lower tax reform and the regulation to improve immigrant housing for rental lender, etc. This policy will be useful for foreign capital to understand Russia's market and invest it. Though we need to analyse our results further,our original questionnairesurvey uniquely shows a lot of real immigrant's housing.

(C) Michigami M., 2018

This work is licensed under a Creative Commons Attribution 4.0 International License

\section{References}

Avito.ru, real estate. (21-28 April 2018). Available at: https://www.avito.ru/nefteyugansk/nedvizhimost

Ashkenazi L., Vekshtein M. (2009). Natsionalnye predpochteniya pri arende zhilploshadi v Moskve, ili «krome KKA i Azii» [National preference when renting housing space in Moscow or "except for Caucasian and Asian”]. Vestnik Obschestvennogo Mneniya, 99(1), 97-100 (In Russ.) 
Demintseva Y. (2014). The New Muscovites, Migrants from Central Asia. Russia in global affairs, (1). Available at: http://eng.globalaffairs.ru/number/The-New-Muscovites-16509

Demintseva E., Peshkova V. (2014). Migranty iz Srednei Asii v Moskve [Migrants from Central Asia in Moscow]. Demoscope, 597-598. Available at: http://www.demoscope.ru/weekly/2014/0597/ tema01.php

Demintseva E. (2017). Labour Migrants in Post-Soviet Moscow: Patterns of Settlement. Journal of Ethnic and Migration Studies, 43(15), 2556-2572. (In Russ.)

Fedotenkov I., Mikolajun I. (2013). Migration and Welfare. International Atlantic Economic Society, $19,71-73$.

Kashnitsky I., Gunko M. (2016). Spatial variation of in-migration to Moscow: Testing the effect of housing market. Cities, 59, 30-39.

Limonov L., Nesena M. (2016). Regional cultural diversity in Russia: does it matter for regional economic performance? Area Development and Policy, 1(1), 63-93.

Michigami Mayu (2016). Shijohendou ni yureru Rosia Toshi Juutaku [Russian Urban Housing swaying to the Market Fluctuation]. In Koji Nakatsu (ed.). Kironitatsu Chugoku to Rosia [China and Russia at the Crossroad]. Soseisha, 171-192. (In Japanese.)

Michigami Mayu (2017). Immigrants' housing environment and multi-layered structure of housing market in Russia: from the interim results of sociological questionnaire. Migratsiya i sotsialinoekonomicheskoe razvitie, (4). (Forthcoming.)

Michigami Mayu (Mimeo). Perspectives and Obstacles of Urban Planning Business on the JapanRussia Economic Cooperation: Uncertainty of Investment, Law, Household Income, and Business Matching for Japanese Housing Related Industries. Annual International Conference "Evolution of International Trading System: Prospects and Challenges".

Rosstat (2012, 2016). Rossiyskaya Statisticheskaya Ezhegodnik [Russian Statistical Yearbook]. Moscow: Rosstat Publ.

Rossiskaya Gazeta. (23 august 2017). https://rg.ru/2017/08/23/reg-cfo/v-moskve-ceny-na-arendukvartir-ostalis-prezhnimi.html.

Sigarev A.V., Kosov M.E. (2016). Spetsifika primeneniya tsenovoi diskriminatsii pri realizatsii informatsionnykh blag pocredstvom elektronnoi torgovli [Specificity on the application of price discrimination in the implementation of information goods through electronic commerce]. Finansovaya analitika: problem i resheniya, 9(10), 22-30. (In Russ.)

OOO "Sterniks konsoliting" [Sternyk Consulting]. (2017). Zhilishny rynok gorodov Rossii v 1 polgody 2017 g.: stagnatsiya nadolgo [Housing market in Russian cities in the first half of 2017: long stagnation]. Moscow. Available at: http://realtymarket.ru/

Tang Z., Smith M.D., Montgomery A. (2007). The Impact of Shopbot Use on Prices and Price Dispersion: Evidence from Online Book Retailing. Working paper. Heinz College Research, Carnegie Mellon University. Available at: http://repository.cmu.edu/cgi/viewcontent.cgi?article $=1046 \&$ context $=$ heinzworks.

TSIAN: real-estator website. (3 September and 7 November 2017). Available at: https://www.cian.ru/

Vendina O.I. (2004). Mogut li v Moskve vozniknut' etnicheskie kvartili? [Can the ethnic apartment be born in Moscow?]. Vestnik Obschestvennogo Mneniya, (3), 52-64. (In Russ.)

Vendina O.I. (2005). Migranty v Moskve: grozit li rossiyskoi stolitse etnicheskaya segregatsiya? [Migrants in Moscow: does the ethnic segregation threaten Russian capital?]. Migratsionnaya situatsiya $v$ regionakh Rossii, (3). (In Russ.)

Zaionchkovskaya Zh.A., Mkrtchan N.V., Vendina O.I., Tyuryukanova E.V., Ivanova T.D., Gel'bras V.G. (2009). Immigranty v Moskve [Immigrants in Moscow]. Moscow, Center of Migration Research, Institute Kennan. (In Russ.) 
Acknowledgements:

The study was supported by JSPS KAKENHI, Grant Numbers 15KK0079 , 26504005, 26245034, $17 \mathrm{~K} 02108$.

Article history:

Received: 01 June 2018

Revised: 05 August 2018

Accepted: 29 September 2018

\title{
For citation:
}

Michigami M. (2018). Immigrants' housing in the housing market in Russia: from the results of sociological questionnaire. RUDN Journal of Economics, 26(3), 531-542. DOI: 10.22363/23132329-2018-26-3-531-542

Bio note:

Michigami Mayu, Ph.D of Economics, Associate Professor, Faculty of Economics, Niigata University (National University). Contact information: e-mail: michigami@econ.niigata-u.ac.jp

\section{Жилищные условия иммигрантов на рынке жилья в России: результаты социологического исследования}

\author{
М. Мичигами \\ Университет Ниигаты \\ 8050, Икараши 2-но-чо, Ниси-ку, Ниигата, 950-2181, Япония
}

Исследование основано на результатах социологического опроса, проведенного автором в 25 городах России с июня 2017 по март 2018 г. Особое внимание уделяется трудовым иммигрантам из Центральной Азии, Украины, Беларуси и Кавказа в России. Статья основана на следующих положениях: во-первых, соотношение между демографическими характеристиками и сферой арендного жилья в России, во-вторых, многослойная структура и неформальность российского рынка жилья, наконец, связь между условиями и производительностью труда трудовых мигрантов.

В заключение указывается, что российский рынок жилья отделен от рынка жилья мигрантов. Жилищные сделки с мигрантами, возможно, являются теневой частью российского рынка жилья. Большая часть сделок на данном рынке проходит вне поля официальной статистики. Все это является препятствием для потенциальных иностранных инвесторов. Кроме того, качество жилищных условий иммигрантов слишком низкое, чтобы поддерживать их производительность труда на высоком уровне. Нужно стремиться к улучшению жилищных условий для трудовых иммигрантов и созданию более прозрачного рынка жилья в России.

Ключевые слова: жилищные условия, иммигрант, сегрегация, неформальность, многослойная структура, рынок аренды жилья, Россия 


\section{История статьи:}

Дата поступления в редакцию: 01 июня 2018

Дата проверки: 05 августа 2018

Дата принятия к печати: 29 сентября 2018

\section{Для цитирования:}

Мичигами М. Жилищные условия иммигрантов на рынке жилья в России: результаты социологического исследования // Вестник Российского университета дружбы народов. Серия: Экономика. 2018. Т. 26. № 3. C. 531-542. DOI: 10.22363/2313-2329-2018-26-3-531542

\section{Сведения об авторах:}

Мичигами Маю, доктор экономических наук, доцент экономического факультета Университета Ниигаты, Япония. Контактная информация: e-mail: michigami@econ.niigata-u. ac.jp 